\title{
(ख) W
}

ISSN 2450-6486

www.ehs-ss.pl

DOI: 10.38014/ehs-ss.2020.3-1.14

УдК 640.4:[614.46:616.91

\section{Olena VASILENKO, Elena OVCHINNIKOVA}

\section{Peculiarities of formation of innovative approaches to the development of hotel and restaurant business in conditions}

\begin{abstract}
OLENA VASILENKO, ELENA OVCHINNIKOVA. Peculiarities of formation of innovative approaches to the development of hotel and restaurant business in conditions. The relevance of the study is to create conditions and ensure the functioning of hotel and restaurant businesses in the conditions imposed by the state, quarantine restrictive measures in connection with the pandemic of viral diseases. The purpose of research. Scientific substantiation, features and practical recommendations for the introduction of robotic and automated systems that will allow hospitality enterprises to operate in the conditions imposed by the state quarantine restrictive measures. Methods. The methodological basis of the study is a comprehensive approach between problem statement and analysis of research results using new modern approaches. The scientific novelty lies in the regularity of processes and scientific substantiation of the latest technologies and methods of effective use in the hotel and restaurant business in the context of viral diseases. Conclusions. The introduction of innovative development of enterprises in the hotel and restaurant business,
\end{abstract}


namely the use of robotics and automation during a pandemic, is analyzed and proposed.

Keywords: hotel and restaurant business; hospitality industry; innovations; robotics in the hotel and restaurant business; hospitality during a pandemic.

The urgency of the problem. Formulation of the problem. According to the site http: nv.ua, there are 209 countries in the world where the COVID-19 virus has been detected. The total number of cases of infection as of 07.04.2020 was 1 million 374 thousands of persons.

The outbreak has been declared a pandemic by the World Health Organization. As a result, governments in almost all countries have introduced unprecedented quarantine measures that have led to the closure of hotels and restaurants around the world. Given this, the search for new innovative ways of working in a pandemic is an urgent problem. At the same time, there have been cases of pandemics of various viral diseases in the world for the last 20 years, which has led to a decrease in demand for hotel and restaurant business services, and in some cases the actual cessation of this activity.

The state of study of the problem. Fundamental theoretical aspects of the problems of formation of innovative development of hotel and restaurant business are reflected in the works of the following scientists: A. Bakaev, V. Besedin, O. Gavrilyuk, A. Galitsky, V. Geets, A. Gradov, N. Kovtun, V. Korneev, M Krachilo, A. Muzychenko, B. Panasyuk, V. Savchenko, V. Seminozhenko, D. Stechenko, O. Udalykh, V. Shevchuk, L. Fedulova, A. Chukhno and others.

Unresolved issues. At the heart of the views of the above scientists is the development of hotel and restaurant business in terms of strategy. Their research was based on the hotel and restaurant industry as separate components of the hospitality industry. They did not focus on the development of innovation in the hotel and restaurant business, nor did they address issues related to the conditions of the pandemic viral disease, which is becoming widespread and is a significant obstacle to the sustainable development of the industry.

Purpose and methods of research. The purpose of the article is to determine the prospects for the development of hotel and restaurant business during and in a pandemic. Current state and further implementation of innovative systems for the efficient operation of the hospitality industry. 
The methodological basis of the study is the scientific works of domestic and foreign scientists on the development of hospitality in viral diseases. The realization of the purpose is based on a systematic approach to the researched problem.

The research methods were carried out by processing scientific publications on the management of the hotel and restaurant business during the pandemic.

The information base of the study consisted of monographs, scientific articles, materials of scientific and practical conferences, publications of domestic and foreign scientists, electronic resources and periodicals.

Object of research: technology of introduction of innovative tools for effective work of the hospitality sphere in the conditions of a pandemic of viral diseases.

Subject of research: features of rational and continuous work of hotel and restaurant business by use of robotics and automation.

Results of the research. The pandemic (quarantine) is a tremendous blow to the world and Ukrainian markets. Marina Leo, DEOL Partners, CEO 11 Mirrors Design Hotel and the Senator Hotels and Apartments network provide data from the UN World Tourism Organization (UNWTO): in 2020 the number of tourists will decrease by almost a quarter compared to 2019.

50 million jobs related to the tourism industry are under threat. According to her, this cannot but be reflected in the sphere of hospitality in Ukraine. After the introduction of quarantine, 35-40\% of hotels in Ukraine have closed, others work in a limited mode, but according to experts, they have already lost $60-90 \%$ of income.

According to the study, the leader in the rate of loss is the hotel business. According to the American company STR, in 2020, the first week of March, hotel occupancy in the United States fell to $61.8 \%$ compared to $66.6 \%$ a year earlier, the leading hotel business in terms of loss.

The main negative consequences of the pandemic and the quarantine announced for it for the hotel and restaurant business, along with the loss of guests, are the cash gap. This has necessitated many companies to release almost all employees on vacation at their own expense, to stop advertising campaigns and other expenses.

Almost every year, Ukraine is affected by the flu epidemic, there is an outbreak of more rare diseases, and some epidemics become chronic.

In Ukraine, over the past 25 years, the highest number of cases of cholera was registered in 1994 (845 cases) and 1995 (548 cases). In 2011, a resonant outbreak of cholera was registered in Mariupol, Donetsk region 
(33 patients, 24 carriers of Vibrio cholera). The last outbreak of cholera in the Donetsk region was recorded in 2011.

The H1N1 flu epidemic in Ukraine began in autumn 2009. Quarantine with a ban on holding mass events was in effect in 9 oblasts. As of November 5, 2009, more than 763 thousand patients with influenza and acute respiratory diseases were registered in Ukraine. Over the past 15 years, three epidemic outbreaks of measles have been recorded with an interval of 5-6 years. During these years, the incidence has increased tenfold, according to the Ministry of Health. As of November 1, 2017, 2,381 people fell ill with measles in Ukraine. This is 70 times more than a year earlier (In Ukraine, the incidence of measles is growing, 2017)

The dynamics of the incidence of influenza and SARS during the epidemic season 2019/2020 see in our infographic (Fig. 1).

From March 30 to April 5, 105,116 people fell ill with SARS and influenza in Ukraine. $39.5 \%$ of them are children under 17 years old. One person died from complications from the flu.

\section{ДИНАМІКА ЗАХВОРЮВАНОСТІ НА ГРИП ТА ГРВІ В УКРАÏHI}
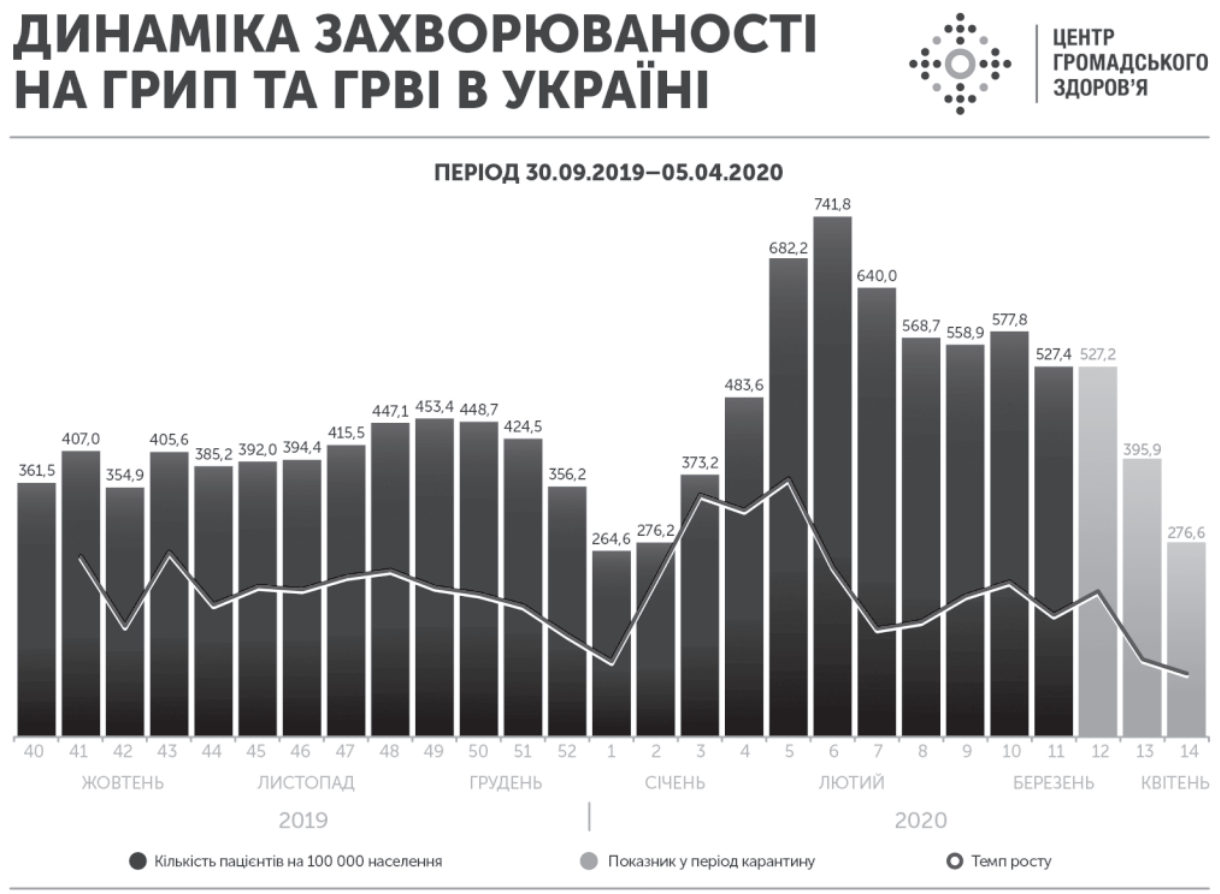

Fig.1. Dynamics of influenza and SARS in Ukraine (Dynamics of the incidence of influenza and SARS in Ukraine, 2020) 
The intensive incidence rate was 274.9 per 100,000 population ("Dynamics of influenza and SARS in Ukraine", 2020).

Studies show that any viral diseases and quarantine measures lead to destabilization of the hotel and restaurant business.

In the hospitality industry, there were about one-third fewer visitors.

The main component of the tourism industry, which involves the movement of large numbers of people as potential carriers of viral diseases, is the hotel and restaurant industry. Therefore, the threat of the spread of viral diseases in the world and our country, the risk of state imposition of appropriate quarantine restrictive measures, as well as concern for the safety and health of consumers and staff requires finding ways to safe, continuous and profitable operation of hotel and restaurant industry in such conditions.

Given the above, it is important to respond to changes promptly and make extraordinary decisions focusing on innovation.

In the production of restaurant services, the main types of innovations are technical, organizational - technological, managerial, complex. Technical innovations are associated with the introduction of new types of equipment, the introduction of computer technology, the spread of information technology innovations that facilitate work with guests and help improve the overall process of service production. Organizational and technological innovations are associated with new types of services (Finogeeva SM, Kolosinskaya NM, 2018)

Comprehensive robotics and automation of hotels, including booking processes, settlements with guests, agents, tour operators and business activities, customer service with minimal contact with them and ensuring their comfort at a high level are rational for the hotel industry in quarantine.

The robot can directly execute the operator's commands, can work on a pre-compiled program or follow a set of general instructions using artificial intelligence technology. These tasks allow to facilitate or completely replace human labor in production, construction, when working with heavy loads, harmful materials, as well as in other difficult or dangerous conditions for humans.

The process of robotization of production plays an important role in the enterprise. Human power is being replaced by robotic systems. Their main advantage is that they can be reconfigured at any time for completely different tasks, which is important for the hotel and restaurant industry during quarantine.

Due to the use of such robotics, the company manages to achieve 
significant savings. Robotization is considered as one of the most effective methods of solving the problem of personnel in the future.

More and more hotel and restaurant business owners are considering integrating technology to optimize service speeds and save wages.

According to experts, robotics and automation continue to win the hotel and restaurant business. First of all, these are technologies and systems that allow saving resources and optimizing staff work. Successful experiments include robot bartenders, assistant chefs and waiter jobs in restaurants.

The world's first fully robotic restaurant is Spyce in Boston, which opened in 2018. The concept was developed by graduates of the Massachusetts Institute of Technology Kale Rogers, Michael Farid, Brady Knight and Luke Schlueter.

The restaurant has an open kitchen, where there are seven autonomous units for cooking. Visitors have the opportunity to choose from the electronic menu one of the dishes of international cuisine. Then the ingredients automatically fall into one of the cooking machines. There are two chefs in the whole restaurant, who are engaged in slicing products and serving.

The offered restaurants will have all automated processes: ordering, preparation and direct preparation of culinary products, serving dishes and serving tables. Sometimes people have to intervene in the process - for example, in emergencies or when you need to replenish the ingredients of a chef.

Restaurants with vending machines use shows, for example in San Francisco CafeX uses only one automatic hand to knock down lattes and cappuccinos.

The Las Vegas vending machine is designed for making burgers, which produces 400 burgers per hour.

In the shopping and business district of Tokyo, a new cafe has opened, a one-armed robot named Sawyer works as a barista.

According to the Associated Press, the robot takes a few minutes to complete the order. Sawyer can serve up to five people at a time, such a cup of coffee costs 320 yen (about \$3). The barista robot can prepare other hot drinks, including cappuccino, tea and hot chocolate.

In 2019, Picnic introduced a robot that prepares 300 pizzas per hour thanks to artificial intelligence, cloud technology and proprietary automation tools. Particular attention was paid to the company Dishcraft Robotics, which introduced the first robot dishwasher for 
restaurants and cafes.

One of the pizzerias in Pakistan is experiencing a real boom, after the owners decided to use a waitress robot in their cafe, the Associated Press reported.

According to the developer, his robot can meet and greet guests at the entrance, and then serve the ordered pizza. The robot is made in the form of a short slender woman in a long dress and apron.

According to the owner's statistics, after the appearance of the first robot in the pizzeria, sales have doubled. Currently, there are three "robot-waitresses". The owner of the pizzeria plans to open several establishments with works.

The travel agency H.I.S., which owns the innovative cafe, notes many positive aspects in the use of robots. According to Masataka Tamaki, director of corporate planning at H.I.S., a robotic café requires only one living employee, while regular coffee shops employ several people.

In the near future, China plans to open about 1,000 robotic restaurants.

In mid-January 2020, Chinese developer Country Garden Holdings opened China's first fully robotic restaurant in Guangzhou. The restaurant uses robots to prepare and deliver culinary products, take orders and serve guests. Only in the production process employed 32 robots who prepare new dishes. Robot waiters greet guests at the entrance. They select a free table for visitors, recommend special offers of the day and accept orders.

In early April 2020, Miso Robotics introduced food processors for fast food restaurants that should automate industrial kitchens. The decline in business activity as a result of the COVID-19 pandemic is harming the services segment, but the company is confident that the work will help reduce costs and at the same time increase the efficiency of the hotel and restaurant industry. The software allows the work to cook more than a dozen dishes, including chicken wings, meat appetizers, french fries, cheese sticks, popcorn with shrimp and chicken, as well as onion rings.

The company plans to install robots in more than 50 fast-food restaurants around the world.

In places where people gather, devices are installed that are automatically able to prepare simple meals in front of the guest. Most often, these are machines for selling hot dogs and pizza. Of course, the base is prepared in advance, the devices themselves are not able to perform the entire cooking cycle, but its final stage of assembly and heating-completely.

The coronavirus pandemic is accelerating the introduction of new technologies in tourism. To minimize the contacts of guests in hotels began 
to service the work. Hoteliers are convinced that this is just the beginning: the need for such a service will only grow. While in the context of the COVID-19 pandemic, hoteliers around the world are cutting staff, the Hong Kong hotel operator L'hotel Group, on the contrary, has hired a new employee. His name is Genie: it is the first of three artificial intelligence robots to serve 432 rooms at L'hotel Island South.

The main functionality of Genie is the delivery of products to the rooms, including those who are in quarantine. Genie has become popular: a day he delivers from 130 to 150 orders, and some guests specifically apply to the room service for food delivery to take pictures of such an unusual "employee".

Hoteliers hope that the work will be their "practical" advantage: for fear of catching the coronavirus, tourists are asked to minimize contact with other guests and staff.

According to representatives of the hotel sector, the need for "contactless" guest service will become a "megatrend" in the next five years.

The most effective and useful to date were the supplier works. Devices of various modifications from the American company Savioke are actively gaining popularity and are successfully used. They can deliver to the guest room various small orders from the concierge service, it can be towels, drinks or correspondence. It is enough for the employee to put the necessary work in a box on the top panel, to specify room number and to press "Go". The robots are equipped with several bars of luxury hotels and cruise liners, which have already prepared more than a million cocktails. Nino has two "hands" with which he mixes and shakes, and then serves ready-made drinks. The machine can mix cocktails from 170 bottles for literally every taste: through the mobile application you can order a cocktail with famous recipes or come up with your own. Nino, this is an updated version of the already functioning Bionic Bar model of the Makr Shakr brand, which appeared in 2013.

Thanks to the forecasts of experts, robotics and automation continues to win the hotel and restaurant business, which is becoming an integral part of many work processes. First of all, these are technologies and systems that allow saving resources and optimizing staff work. Successful experiments include robot bartenders, assistant chefs and waiter robots in restaurants and robot suppliers in hotels.

At present, the robotics market in Ukraine is just emerging.

Automation also improves the efficiency of the hotel, providing owners and managers with a wide range of tools for management and 
analysis, and employees with new opportunities for productive work.

The following systems are effectively implemented: automation of bars, restaurants, HMS hotel management, online hotel booking, hotel security and access control and hotel staff management.

Modern hotels need to innovate in the restaurant industry. This is not only the management of the restaurant, but also many auxiliary automated tools, such as: interactive menu, screens, tablets on tables, touch screens (Kabanchuk V.Yu., 2019).

Automation of hotel and restaurant business provides an opportunity to work effectively. The owners almost immediately note the positive dynamics in the field of hospitality. For staff, such opportunities make it easier to perform their duties, reduce time for product accounting and costing. Abuse of employees stops.

The hotel industry uses the following latest information technologies, namely: integrated communication networks, multimedia systems, management information systems, global computer reservation systems. Modern information technologies have the greatest impact on the promotion of the hotel product. In recent years, hotel companies have created their websites on the Internet. Sending advertising information by e-mail - direct mail. High reliability and convenience of computer reservation systems CRS (Computer Reservation System), which allowed to speed up the backup process and carry it out in real-time.

When planning and building the modern hotel and restaurant complexes, the main attention is paid to saving time, money and energy. To save energy, create environmentally friendly technologies. An example of a hotel with the latest modern technology is the Innovation Hotel - an innovative eco-hotel belonging to the IHG. Eco-hotels have solar panels on the roof to heat water, wind generators to generate electricity, recycled windows, furniture made entirely of recycled materials. Non-toxic paints are used in the treatment. It is especially interesting that used oil from the kitchen will be used as biofuel (Chernomazyuk AG, 2014).

The competitiveness of the enterprise is influenced by many factors: location, size of the number of rooms, category, infrastructure, material and technical condition, cost of living, the presence of architectural monuments and others. Today it is impossible to limit oneself to the above factors. New ideas are needed for the hotel's continued success. It is competition that stimulates the emergence of new ideas and the introduction of additional services. New management methods, modern technologies, qualified specialists and a high level of service can constantly generate hotel revenue. 
Modern hotels use new advanced technologies of tourist services in the process of providing services, such as: introduction of plastic cards, automatic telephones, computers, machines for transmission of facsimile images.

The development of congress tourism has formed a demand for the organization based on hotels of various conferences, symposia and trainings for staff. The organization of these events today remains the main source of additional income for hotels. (Pucenteilo PR, 2007).

Given the above, we can conclude that the hotel and restaurant business is constantly changing. This is due to the fact that the sphere of hospitality depends entirely on the impressions of consumers. The impressions depend not only on the quality of services, but also on the location of the subject, the political and economic situation of the region, the country (Volkovskaya YV, 2015).

According to analysts at the Pew Research Center, by 2025 there will be a trend in the hospitality industry, but robots will not replace people, but the hospitality industry will use the model of partial robotics and automation for convenience and ease of work processes, especially a crisis.

Conclusions and discussion of results. According to business associations, due to the difficulty of predicting the potential extent of the virus in Ukraine, it is virtually impossible to digitize potential losses in the hotel and restaurant sector due to the pandemic.

The activities of institutions that have officially ceased are trying to urgently refocus on delivery. Hospitality companies that did not have time to reorient are planning to connect to services such as Glovo or Uber Eats. Most establishments organize their delivery, turning the waiters into temporary couriers.

Formats of establishments that did not work with delivery before bars, pubs, cafes, karaoke establishments, hookahs offer promotions, as well as discounts for self-pickup of food and beverages.

Some restaurateurs believe that it is better to wait a while for a decision on a new format of work. Among 150 restaurateurs and franchisors of Ukraine surveyed assistance to the industry. According to entrepreneurs, the state can develop support measures, but these are temporary proposals that do not completely solve the problems of the hotel and restaurant industry.

According to experts, the crisis in the hotel and restaurant industry may last from two to four years, but this time will provide an even stronger impetus to the rapid development of technologies such as: 
- Artificial Intelligence;

- Software interfaces;

- Augmented reality;

- Use of voice assistants;

- Biometrics, face recognition.

The results of the study allow us to understand that the use of robotics and automation in the hotel and restaurant business solve the following problems:

- increase competitiveness;

- reduce fixed costs;

- increase economic efficiency;

- continuous work in a pandemic.

The scientific novelty of the obtained results lies in the regularity of processes and scientific substantiation of the use of new technologies such as robotics and automation in the hotel and restaurant industry, methods of its efficient use and ways to improve performance and income.

The practical significance of the obtained results is manifested in the introduction of robotics and automation, which will allow enterprises in the hotel and restaurant business to work effectively in any conditions.

Prospects for further research are to improve and use the latest technologies in the hotel and restaurant industry through the introduction of robotics and automation will enable enterprises to work effectively in any crisis.

\section{References:}

1. Volkovskaya, Ya.V. (2015). Trends in the development of hotel and restaurant business in Ukraine. Scientific Bulletin of the International Humanities University, 82-85. Retrieved from http://vestnik-econom.mgu.od.ua/ journal/2015/12-2015/19.pdf

2. The incidence of measles is growing in Ukraine. (2017). Ministry of Health of Ukraine. Taken from https://moz.gov.ua/article/news/v-ukraini-zrostaezahvorjuvanist-na-kir.

3. Dynamics of influenza and SARS in Ukraine. (2020). Center for Public Health of the Ministry of Health of Ukraine. Taken from https://www.phc.org.ua/news/ dinamika-zakhvoryuvanosti-na-grip-ta-grvi-v-ukraini.

4. Kabanchuk V.Yu. (2019). Modern directions of economic development, entrepreneurship, technologies and their legal support. Proceedings of the scientific conference of LTEU students, 71-73. Taken from https://tourlib.net/ statti_ukr/kabanchuk.htm

5. Pucenteilo PR (2007). Functional purpose of hotel rooms. Economics and 
organization of tourist and hotel business. Retrieved from https://tourlib.net/ books_ukr/pucentejlo94.htm

6. Finogeeva, SM, Kolosinskaya NM (2018). Innovative approaches to the development of hotel and restaurant business in Ukraine. Abstracts of the All-Ukrainian scientific-practical conference of Mukachevo State University "Prospects for the development of the hotel and restaurant industry of Ukraine: theory, practice, innovation of development", 108-110. Taken from https://msu. edu.ua/wp-content/uploads/2018/04/materialy-conference 2018-pdf.pdf

7. Formation of a competitive hotel industry in the region. (2017). Retrieved from https://www.uzhnu.edu.ua/en/infocentre/get/14429

8. Chernomazyuk AG (2014). Innovations in the field of hotel and restaurant business. Bulletin of Khmelnytsky National University. Economic Sciences, 5, 2, 269-272. Retrieved from https://tourlib.net/statti_ukr/chernomazyuk.htm.

9. Dorothy Creamer, Editor-in-Chief, Michal Christine Escobar, Managing Editor and Anna Wolfe. 08/16/2019. Mission Innovation. HT Hospitality Technology. Smarter Hotels \& Restaurants

10. Ivanov S., Craig W., Berezina K. (2017). Adoption of robots and service automation by tourism and hospitality companies. Revista Turismo \& Desenvolvimento, 5/6, 28, 1501-1517.

11. Ivanov S., Craig W., Garenko A. (2018). Young Russian adults attitudes towards the potential use of robots in the hotel. Technology in Society, 55, 24-32.

12. Ivanov S., Craig W. (2019) Robots, Artificial Intelligence, and Service Automation in Travel, Tourism and Hospitality.

\section{Transliteration of References:}

1. Chernomazjuk A.Gh. (2014). Innovaciji u sferi ghoteljno-restorannogho biznesu. [Innovations in the field of hotel and restaurant business]. Visnyk Khmeljnycjkogho nacionaljnogho universytetu. Ekonomichni nauky, 5, 2, 269-272. Retrieved from https://tourlib.net/statti_ukr/chernomazyuk.htm [in Ukrinian].

2. Dorothy Creamer, Editor-in-Chief, Michal Christine Escobar, Managing Editor and Anna Wolfe. 08/16/2019. Mission Innovation. HT Hospitality Technology. Smarter Hotels \& Restaurants.

3. Dynamika zakhvorjuvanosti na ghryp ta GhRVIv Ukrajini.[Dynamics of influenza and SARS in Ukraine]. (2020). Centr ghromadsjkogho zdorov'ja MOZ Ukrajiny. Retrieved from https://www.phc.org.ua/news/dinamika-zakhvoryuvanosti-nagrip-ta-grvi-v-ukraini [in Ukrinian].

4. Finoghjejeva, S.M., Kolosinsjka N.M. (2018). Innovacijni pidkhody rozvytku ghoteljno-restorannogho biznesu $\mathrm{v}$ Ukrajini. [Innovative approaches to the development of hotel and restaurant business in Ukraine]. Perspektyvy rozvytku ghoteljno-restorannoji industriji Ukrajiny: teorija, praktyka, innovaciji rozvytku, 108-110.Retrieved from https://msu.edu.ua/wpcontent/uploads/2018/04/ materialy-konferenciji 2018-pdf. [in Ukrainian]. 
5. Formuvannja konkurentospromozhnogho ghoteljnogho ghospodarstva reghionu. [Formation of a competitive hotel industry in the region] (2017). Retrieved from https://www.uzhnu.edu.ua/uk/infocentre/get/14429 [in Ukrinian].

6. Ivanov S., Craig W., Berezina K. (2017). Adoption of robots and service automation by tourism and hospitality companies. Revista Turismo \& Desenvolvimento, 5/6, 28, 1501-1517. [in English].

7. Ivanov S., Craig W., Garenko A. (2018). Young Russian adults' attitudes towards the potential use of robots in the hotel. Technology in Society, 55, 24-32. [in English].

8. Ivanov S., Craig W. (2019). Robots, Artificial Intelligence, and Service Automation in Travel, Tourism and Hospitality. [in English].

9. Kabanchuk V.Ju. (2019). Suchasni naprjamy rozvytku ekonomiky, pidpryjemnyctva, tekhnologhij ta jikh pravovogho zabezpechennja.[Modern directions of economic development, entrepreneurship,technologies and their legal support]. Materialy naukovoji konferenciji studentiv LTEU, 71-73. Retrieved from https://tourlib.net/statti_ukr/kabanchuk.htm [in Ukrinian].

10. Pucentejlo P.R. (2007). Funkcionaljne pryznachennja ghoteljnykh nomeriv. [Functional purpose of hotel rooms]. Ekonomika i orghanizacija turystychnoghoteljnogho pidpryjemnyctva. Retrieved from https://tourlib.net/books_ukr/ pucentejlo94.htm [in Ukrinian].

11. Volkovsjka, Ja.V. (2015). Tendenciji rozvytku ghoteljno-restorannogho biznesu v Ukrajini [Trends in the development of hotel and restaurant business in Ukraine]. Naukovyj visnyk Mizhnarodnogho ghumanitarnogho universytetu, 82-85. Retrieved from http://vestnik-econom.mgu.od.ua/journal/2015/12-2015/19.pdf. [in Ukrainian].

12. V Ukrajini zrostaje zakhvorjuvanistj na kir. [The incidence of measles is growing in Ukraine] (2017). Ministerstvo okhorony zdorov'ja Ukrajiny. Retrieved from https://moz.gov.ua/article/news/v-ukraini-zrostae-zahvorjuvanist-na-kir [in Ukranian].

\section{The Author}

Olena Vasilenko

Candidate of Pedagogical Sciences,

Kyiv University of Culture,

Kyiv, Ukraine,

ORCID ID: 0000-0003-4097-7476

E-mail:terlen@ukr.net

Elena Ovchinnikova

Undergraduate Student, 
Kyiv University of Culture,

Kyiv, Ukraine,

E-mail: ovchinnkova79@icloud.com

Abstracts

ОЛЕНА ВАСИЯЕНКО, ОЯЕНА ОВЧІННІКОВА. ОсОблИВОсті формування інноваційних підходів розвитку готедьно-ресторанного бізнесу в умовах пандемії. Актуальність дослідження полягае у створенні умов та забезпеченні функціонування підприємств готельно-ресторанного бізнесу в умовах, запроваджених державою, карантинних обмежувальних заходів у зв'язку із пандемією вірусних захворювань. Мета досліджень: наукове облрунтування, особливості і практичні рекомендації щздо впровадження роботизованих та автоматизованих систем, які дозволять підприемствам сфери гостинності функціонувати в умовах, запроваджених державою карантинних обмежувальних заходів. Методи: методологічною основою дослідження є комплексний підхід між постановкою завдання та проведенням аналізу результатів дослідження із використанням нових сучасних підходів. Наукова новизна полягае у закономірності процесів та науковому облрунтуванні новітніх технологій та методів ефективного використання у сфері готельно-ресторанного бізнесу в умовах вірусних захворювань. Висновки: проаналізовано і запропоновано впровадження інноваційного розвитку підприємств сфери готельно-ресторанного бізнесу, а саме використання роботизації та автоматизаціiі під час пандеміï.

Ключові слова: готельно-ресторанний бізнес; індустрія гостинності; інновацїі; роботизація в готельно-ресторанному бізнесі; сфера гостинності під час пандемї.

\section{ЕЛЕНА ВАСИЛЕНКО, ЕЛЕНА ОВЧИННИКОВА. ОсобенНо- сти формирования инновационных подходов развития гостинично-ресторанного бизнеса в усдовиях пандемии. Актуальность исследования заключается в создании условий и обеспечении функциионирования предприятий гостинично-ресторан- ного бизнеса в условиях, введенных государством, карантинных огра- ничительных мер в связи с пандемией вирусных заболеваний. Цель исследований: научное обоснование, особенности и практические рекомендации по внедрению роботизированных и автоматизирован-}


ных систем, которые позволят предприятиям сферы гостеприимства функционировать в условиях, введенных государством карантинных ограничительных мер. Методы: методологической основой исследования является комплексный подход между постановкой задачи и проведением анализа результатов исследования с использованием новых современных подходов. Научная новизна заключается в закономерности процессов и научном обосновании новейших технологий и методов эффективного использования в сфере гостинично-ресторанного бизнеса в условиях вирусных заболеваний. Выводы: Проанализировань и предложено внедрение инновационного развития предприятий сферь гостинично-ресторанного бизнеса, а именно использование роботизации и автоматизации во время пандемии. Ключевые слова: гостинично-ресторанный бизнес; индустрия гостеприимства; инновации; роботизация в гостинично-ресторанном бизнесе; сфера гостеприимства во время пандемии.

OŁENA WASYŁENKO, OŁENA OWCZINNIKOWA. Cechy kształtowania innowacyjnych podejść do rozwoju biznesu hotelarskiego i restauracyjnego w warunkach pandemii. Aktualność badania polega na stworzeniu warunków i zapewnieniu funkcjonowania firm hotelarskich $i$ restauracyjnych $w$ warunkach natożonych przez państwo, środków ograniczajacych, wynikajacych z kwarantanny, w zwiazku z pandemia chorób wirusowych. Cel badania: uzasadnienie naukowe, cechy $i$ praktyczne zalecenia dotyczace wprowadzenia zrobotyzowanych i zautomatyzowanych systemów, które umożliwia przedsiębiorstwom hotelarskim działanie w warunkach natożonych przez państwowe środki ograniczajace, wynikające z kwarantanny. Metody: podstawa metodologiczna badania jest kompleksowe podejście pomiędzy postawieniem problemu a analiza wyników badań z wykorzystaniem nowych, innowacyjnych podejść. Nowość naukowa polega na zależności procesów $i$ naukowym uzasadnieniu najnowszych technologii $i$ metod efektywnego wykorzystania w hotelarstwie $i$ gastronomii w kontekście chorób wirusowych. Wnioski: przeanalizowano $i$ zaproponowano wprowadzenie innowacyjnego rozwoju przedsiębiorstw w branży hotelarsko-restauracyjnej, mianowicie wykorzystanie robotyzacji $i$ automatyzacji w czasie pandemii.

Stowa kluczowe: biznes hotelarsko-restauracyjny; przemyst hotelarski; innowacje; robotyzacja w branży hotelarsko-restauracyjnej; gościnność ustugowa w czasie pandemii. 